European Journal of Sustainable Development Research

2019, 3(2), em0085

ISSN: 2542-4742

\title{
EDITORIAL
}

\section{Advances in Sustainable Development Research}

\author{
Marc A. Rosen ${ }^{1 *}$ \\ ${ }^{1}$ Faculty of Engineering and Applied Science, University of Ontario Institute of Technology, 2000 Simcoe Street North, \\ Oshawa, Ontario, L1G 0C5, CANADA
}

*Corresponding Author: marc.rosen@uoit.ca

Citation: Rosen, M. A. (2019). Advances in Sustainable Development Research. European Journal of Sustainable Development Research, 3(2), em0085. https:/ / doi.org/10.29333/ejosdr/ 5730

Published: March 5, 2019

\begin{abstract}
The UN Sustainable Development Goals provide a framework for developing plans and policies for sustainable development, and have spurred an increase in research and activity in this field. There is no single approach to sustainable development, as approaches will vary from country to country, reflecting national and local needs and contexts. But care is needed in moving forward with the Sustainable Development Goals, if their benefits are to be realized. This issue of the European Journal of Sustainable Development Research marks its second anniversary, and demonstrates that the journal has already made a notable impact on the field of sustainable development through having published research on many recent advances.
\end{abstract}

Keywords: sustainable development, sustainable development goals, economic sustainability, environmental sustainability, social sustainability

\section{INTRODUCTION}

In September 2015, the UN General Assembly approved the Sustainable Development Goals (SDGs), including targets and indicators, which countries will use as a framework for 15 years for developing plans and policies. This has led to an increase in research and activity related to sustainable development. The SDGs recognize the three key facets of sustainable development: economic, environmental and social sustainability, and their span across all sectors of societies. The SDGs affect cities and regions facing urbanization, agriculture, infrastructure, transportation, resources (energy, water, materials, etc.), and many other topics.

Care and caution are needed in moving forward with the SDGs, lest their benefits not be fully realized. For instance, economic growth can lift people out of poverty and raise incomes, but it can also cause harm the environment and poorer communities. We need to avoid the problems with past practices, like

- using natural resources inefficiently and wastefully, without accounting for the true costs of their depletion;

- combusting fossil fuels to foster economic growth, without accounting for environmental impacts such as climate change; and

- $\quad$ promoting economic growth in ways that leave a significant percentage of the global population without the benefits, e.g., lacking in adequate nourishment, safe drinking water and access to electricity. 
The need for care and thoughtfulness in implementation is relevant for all 17 of the SDGs, which are as follows:

1. End poverty in all its forms everywhere

2. End hunger, achieve food security and improved nutrition and promote sustainable agriculture

3. Ensure healthy lives and promote well-being for all at all ages

4. Ensure inclusive and equitable quality education and promote lifelong learning opportunities for all

5. Achieve gender equality and empower all women and girls

6. Ensure availability and sustainable management of water and sanitation for all

7. Ensure access to affordable, reliable, sustainable and modern energy for all

8. Promote sustained, inclusive and sustainable economic growth, full and productive employment and decent work for all

9. Build resilient infrastructure, promote inclusive and sustainable industrialization and foster innovation

10. Reduce inequality within and among countries

11. Make cities and human settlements inclusive, safe, resilient and sustainable

12. Ensure sustainable consumption and production patterns

13. Take urgent action to combat climate change and its impacts

14. Conserve and sustainably use the oceans, seas and marine resources for sustainable development

15. Protect, restore and promote sustainable use of terrestrial ecosystems, sustainably manage forests, combat desertification, and halt and reverse land degradation and halt biodiversity loss

16. Promote peaceful and inclusive societies for sustainable development, provide access to justice for all and build effective, accountable and inclusive institutions at all levels

17. Strengthen the means of implementation and revitalize the global partnership for sustainable development

Sustainable development recognizes that growth and economic development must be socially acceptable and environmentally sound to reduce poverty and build prosperity for present populations while not detracting from the ability of future generations meet their needs. Advances in sustainable development are occurring at an increasing pace. These examples include the use of low-carbon energy resources, enhanced public transportation in cities, enhanced environmental and climate practices, improving energy efficiency in buildings and other sectors, improved supply chain efficiencies, and urban planning to enhance productivity. Sustainable development necessitates sound growth policies, coordination of actions and acknowledgement of externalities.

Advances in sustainable development can also be seen through the many examples of actions in line with sustainable development, which are increasingly visible and represented by many articles in the European Journal of Sustainable Development Research. Some of the areas addressed in articles in the journal's first two years include

- general topics like the UN sustainable development goals, environmental attitudes and behaviors, and skills needs for green and low-carbon economies; and

- topics more focused on specific issues, like sustainable urban growth, sustainable land use patterns, food sustainability, teaching and learning strategies and outcomes for sustainable development, and sustainable technology.

Additionally, sustainable energy topics are already well represented in the journal, with articles covering such topics as engines using hydrogen and other clean fuels, advances in wind turbines, energy generation from food waste, and efficient and advanced cooling systems.

There is no single approach to sustainable development, as approaches will vary from country to country, reflecting national and local needs and contexts. Certainly, there will be differences in the approaches of wealthy and poor countries. Many actions can be taken, for example, to support of sustainable urban development in developing or poor countries to improve the lives of citizens, infrastructure, housing, and the environment. Increasing numbers of countries are addressing relations among land, forests, water, and food security more holistically and sustainably, and more are accounting for the value of natural assets and ensuring sustainable use of resources.

Other examples of sustainable development are also evident. One example is the appropriate use of green spaces like parks and other areas where flora and fauna can thrive. These spaces also provide the public with opportunities for recreation, assist in regulating air quality and climate, reduce energy consumption, recharge groundwater supplies and protect lakes and streams from runoff. Another example is exploitation of crop rotation to enhance the growth potential of land and to prevent disease in soil. A third example is the use of efficient water fixtures and appliances to conserve clean water through efforts at the individual and societal levels.

Ensuring the success of sustainable development for present and future generations requires indicators to monitor performance. Standards and tools to support such efforts are continually being developed and refined. 
Examples include enhanced greenhouse gas accounting systems, measures for green development, more meaningful accounting indicators for wealth and its sustainability, and efforts to ensure the sustainability of natural assets like water, land, air and ecosystems.

This issue of the European Journal of Sustainable Development Research marks its second anniversary. The journal has already made a notable impact through having published research related to many areas of sustainable development. Such varied and increasing advances in sustainable development are helping civilization to allow increasingly for "development that meets the needs of the present without compromising the ability of future generations to meet their own needs," and thereby to move towards the definition put forward in 1987 in the Brundtland Report, entitled Our Common Future. 